\title{
THE INTER-WAR ROMANIA'S FOREIGN POLITICS WITH THE COUNTRIES BORDERING THE BLACK SEA. THE CONTRIBUTION OF NICOLAE TITULESCU
}

\author{
Nowadays, nothing is local or even continental anymore, everything is global instead.
} Nicolae Titulescu

\author{
Catalina SZEKELY ${ }^{1}$ \\ ${ }^{1}$ Lecturer PhD Education Sciences Departement Oil and Gas University of Ploieşti
}

\begin{abstract}
The first to intercede in support of reestablishing a peaceful climate after the First World War was the American president Woodrow Wilson, who, in 1919, proposed The Nations' Society Statute to be adopted. Romania was one of the founding members whose remarkable contribution is worth mentioning, Nicolae Titulescu himself holding the presidency of this organization. Foreign relations of Romania in the Balkans, and especially the ones with the countries bordering the Black Sea, were oriented towards creating a stable political space and an anti-revisionist front, as the Balkan area had been continuously affected and influenced by the alliances and confrontations between the countries in this geographical space.
\end{abstract}

Keywords: Black Sea, Balkan, Foreign relations, national sovereignty

Introduction - The end of the 19th century and the beginning of the 20th century were marked by a series of events which would influence Romania's internal and external policy in between the two world wars. Romania has seen some progress in the interwar period and was in full industrialization. In this context, social conditions have undergone a number of changes. Progress and social reforms were struggling with the old mentalities of large landowners, heirs of the ancient royal families, who were reluctant to the new changes in Romanian society. This paper aims to analyze the realities of the interwar period from a social, political and legal perspective, stressing the importance of Romanian diplomacy of that time and of the role played by the illustrious diplomat Nicolae Titulescu.

National context -The economic, social, political and cultural development Romania knew in the inter-war period was the result of the great goals set by the Revolution of 1948, a revolution that led not only to social and economic reforms but also to a change in mentality at society level. Thus, the revolution's ideas promoting freedom of expression, liberation of peasants and land reform, accountability of rulers, national solidarity, etc. led to the great unrest that rocked the Romanian society in the early 20 th century. ${ }^{1}$

Events took place at global level which triggered some changes in Romania as well. Thus, following the Russian Revolution of 1917 which saw the imperial family overthrown, Romanians living in between Prut and Nistru began their

\footnotetext{
${ }^{1}$ Ioan Agrigoroaiei, România Interbelică, vol. I, Alexandru Ioan

Cuza University Press, Iaşi, 2001, p. 11
}

DOI: 10.21279/1454-864X-16-12-085

movement to unite with the country. In April 1917, in Chisinau, the National Moldavian Party was founded, which sought to secure citizen rights and national rights for all Moldovans in Basarabia and beyond Nistru. ${ }^{2}$

The activity of this party and the ideals shared by the respective population led to the Union of Basarabia with Romania in March 1918. At the same time, in Transylvania and Bucovina similar moves took place which ended with the Great Union of 1918.

After the Great Union, Romania started becoming active at European level, being open to economic development which was necessary for it to become a modern state. It is known that during this time Romania has achieved significant victories and coped with the challenges that arose. ${ }^{3}$

Socio-economic life -Starting with the end of the 19th century Romania took a series of measures to encourage and develop national industry. Nevertheless, it is known that Romanian state depended upon foreign capital due to factors such as: international context, lack of technical means, labour force qualification and sometimes raw materials. Romania's economic development thanks to national industry determined a change in the agrarian specific of our country. ${ }^{4}$

\footnotetext{
${ }^{2}$ Idem, p. 12

3 Eugen Stănescu, Iulia Stănescu, Gavriil Preda, România Mare. Puterea politică, Karta-Graphic Publishing, Ploieşti, 2010, p.15

${ }_{4}^{4}$ Emil Cernea, Emil Molcut, Istoria statului şi dreptului românesc, Şansa- Press and publishing S.R.L.,Bucureşti 1998, p. 209
} 


\section{"Mircea cel Batran" Naval Academy Scientific Bulletin, Volume XIX - 2016 - Issue 2 The journal is indexed in: PROQUEST / DOAJ / Crossref / EBSCOhost / INDEX COPERNICUS / DRJI / OAJI I JOURNAL INDEX / I2OR / SCIENCE LIBRARY INDEX / Google Scholar / Academic Keys/ ROAD Open Access I Academic Resources / Scientific Indexing Services / SCIPIO / JIFACTOR}

It is possible Romania would have known a much more obvious progress if losses after the First World War hadn't been so large. Romanian society needed to recover from all points of view: the territory had been warfare theatre, the nouveau riches and little upstarts were trying to seize interwar social and economic life and political parties were supporting them.

A small but sustainable development took place between 1924 and 1928, as proved by the increase in industrial production; all regions were integrated in the unitary economic system by applying economic measures such as: monetary unification and placing all railways into State ownership. Nicolae Titulescu had an important role in implementing these measures; he held the finance portfolio and saw that the balance of trade recovered. All conditions were met for achieving the first Romanian budget after the Great Union, in $1921 .^{5}$

Also in 1921 the land reform was carried out, which exerted a positive influence on Romania's economic, social and political life, contributing, in fact, to a change for the better in peasants' situation, partially solving land issues. ${ }^{6}$

Romania was a predominantly agricultural country which underwent an obvious but not extraordinary evolution; the economic crisis of 1929 - 1933 affected the whole economy, and particularly the agriculture. The social class to suffer the most was peasantry. Legislative changes of 1931 1934 helped diffuse social issues.

Another important aspect of the interwar period was industry which was in a continuous growth; even if economic crisis affected this area equally, after 1933 economic progress was made and the policy meant to encourage national industry went on. In 1938 the national per capita income was 110 dollars, higher than in other European countries like Greece: 76 dollars, Portugal: 81 dollars or Poland: 94 dollars. ${ }^{8}$

Romania gained its independence and more than doubled its territory, gathering around it all Romanian lands around. Modernization intensified its course. Essential reforms were carried out, like the Great Agricultural Reform of 1920 and the universal suffrage. At top level, Romania came to be compared with any Western country. (...) One step below this level and then further down to the base of the social pyramid, the

\footnotetext{
${ }^{5}$ Eugen Stănescu, lulia Stănescu, Gavriil Preda, op. cit., p. 15, see also Kiriţescu, Sistemul bănesc al leului şi procurarea lui, vol. II, Bucureşti, 1967, p. 277

${ }^{6}$ Ioan Agrigoroaiei, op. cit., p. 246

7 Eugen Stănescu, lulia Stănescu, Gavriil Preda, op. cit., pp. 18-21

8 Ibidem
}

picture is no longer the same. It is still a wide area stricken by poverty and illiteracy."

Account should be taken of the fact that overall indicators conceal very sharp social contrasts. Romania stood very well at the higher levels of the elite and very bad at the bottom levels of peasantry. From this point of view, Bulgaria - a country that invites comparison, however inconvenient some Romanians would find this was more balanced, due to the fact that it emerged from a long Ottoman rule without a higher class, being essentially a large peasant society; average rural property was more consistent, agriculture more diverse and productive, peasantry, as a whole, more taken into account by decision makers." ${ }^{10}$

Romania's political life was influenced by the changes that took place at economic, social and legislative level. It is certain that political parties adapted to change, and political activity was conducted according to these realities.

"Oh, it is much easier to criticise than do something (...)... There is a great desire for good in the country, many see that the country is squandering its chances, its development is delayed, and its reputation brought to dust, yet even the well intentioned misuse power when they rise to it. Often prestige is lost not because of their principles but because they are overwhelmed by the situation and they cannot handle the workload, intrigues, corruption, bad habits, envy, greed, dishonesty, laziness. They stumble, their outlook is unclear, their ideal more pallid, without perspective. Few are strong enough to resist and remain faithful to their principles in any circumstance!"11

"Changes occurred in the economic and social life, accompanied by electoral reform that introduced the universal suffrage, have exerted a strong influence on the activity pf political parties, governments and the Parliament. The main trends in political life were dictated by the disappearance of conservative approaches, by the consolidation of the political party of the big bourgeoisie, and the emergence of new political parties."12

The impulse of changes in the area of politics and economy was given by the Constitution of 1923, which took over the provisions of the Constitution of 1866. The new constitution acknowledged the recognition of the national, unitary Romanian state. Another important aspect: the rights and

\footnotetext{
9 Lucian Boia, Suveranii României. Monarhia, o soluţie?, Humanitas Publishing House, Bucureşti, 2014, pp. 77-78

10 Lucian Boia, De ce este România altfel?, ediţia a II-a, Humanitas Publishing House, București, 2013, pp. 76-77

${ }^{11}$ Queen Mary of Romania, see Dan C. Mihailescu, Castelul, Biblioteca, Puscaria. Trei vămi ale feminităţii, Humanitas Publishing House, Bucureşti, 2013, p. 41

${ }^{12}$ Emil Cernea, Emil Molcuţ, op. cit., p. 246
} 


\section{"Mircea cel Batran" Naval Academy Scientific Bulletin, Volume XIX - 2016 - Issue 2 The journal is indexed in: PROQUEST / DOAJ / Crossref / EBSCOhost / INDEX COPERNICUS / DRJI / OAJI I JOURNAL INDEX I I2OR / SCIENCE LIBRARY INDEX / Google Scholar / Academic Keys/ ROAD Open Access I Academic Resources / Scientific Indexing Services / SCIPIO / JIFACTOR}

liberties of Romanian citizens were acknowledged as the foundation of the Constitution.

"Collateral of the reforms that took place in politics after the Union was the adoption of the new Constitution by The Chamber of Deputies, on 26 of March, 1923. Constitution enacted the national and unified, indivisible and independent character of the Romanian state; it has established the rules of organization and enshrined the democratic regime, granting new rights and freedoms for the citizens, including national minorities. The fundamental law of the Romanian state, completed within its historical borders, stipulated the existence of constitutional monarchy, the rule of law in all systems and subsystems of state leadership, the principle of the separation of powers - pledge to achieve real democracy." ${ }^{13}$

After the Great Union, Romanian political life was dominated by the national Liberal Party, even if there were other political parties as well. After 1926, state leadership was alternatively achieved by the two great, and mainly rival, historical political parties: National Liberal Party and the National Peasant Party. National Liberal Party representatives were part of the big industrial and banking bourgeoisie, on the rise at the time. ${ }^{14}$

The fusion between the National Party and the National Peasant Party in 1926 led to the formation of a party that was rivaling the National Liberal Party. As the two great political parties were clashing, other parties started becoming active and would influence the future political life: the Legionary Movement and the Socialist Party. ${ }^{15}$ , I wish I were king (...). I feel I would gather my men together with fierce energy. The strong hand of a master is highly needed. In extreme cases extreme measures are required." ${ }^{16}$

Romanian diplomacy in the interwar period - It is a known fact that Romania made serious efforts after the end of the First World War for the world to acknowledge its new status as a result of changes at state level. Thus, the priority of Romanian diplomacy was not only the recognition of Basarabia's union with Romania, but also the efforts Romania made for keeping peace and setting itself up as an important actor in this difficult process.

An important figure of our diplomacy, recognized internationally, was Nicolae Titulescu, politician and diplomat, who used his leverage internationally so that Romania would reach its

\footnotetext{
${ }^{13}$ Eugen Stănescu, lulia Stănescu, Gavriil Preda, op. cit., pp. 21-22

${ }^{14}$ Emil Cernea, Emil Molcuţ, op. cit., pp. 246-247

${ }^{15}$ Ibidem

${ }^{16}$ Queen Mary of Romania, see Dan C. Mihailescu, op.cit., p. 29
}

DOI: 10.21279/1454-864X-16-12-085

goals and $\mathrm{b}$ acknowledged for its important role in the Balkans.

Nicolae Titulescu asserted in most of his speeches the necessity of keeping peace in Europe and sparing no efforts to achieve this goal. "To prevent war as social phenomenon we must start by blocking war as legal institution. This first goal must respond to new international laws which organize peace. To what extent was this goal achieved? In order to find out, let's hear the critics of today's realists and idealists. Let's only take into account the most serious of arguments, as discussed by the most competent and most representative spokespersons." ${ }^{17}$

Nicolae Titulescu was a personality of international diplomacy, his genius and vision stood at the base of signing important international treaties Romania was part of. The Romanian diplomat made efforts so that stability in the Balkans to be real and he was aware dispute resolution cannot be achieved by open conflict. The role of the League of Nations could be an important one, even if some shortcomings are attributable to this organization, but at the time it was the only way out of tense situations internationally.

"Even if the League of Nations would be guilty of all the sins attributed to it, we still have no other organization to substitute it with. It is the result of a convention between 54 states. Its constitutional organization cannot be subject to debate without the risk of losing the little we gained. Only within the League of Nations and its legal frame can we act to establish international relations on a basis of justice and utility that is required today (...). A war waged in the name of justice will be followed by another war waged in the name of justice. And so on and so forth."18

The Romanian diplomat held the portfolio of the Ministry of Foreign Affairs for only 13 months, but his activity was well known and his presence at the head of the Ministry led to changes for the better and to the reform of the administrative structure of Romanian diplomacy.

Nicolae Titulescu managed to maintain a harmonious climate, although he was confronted with a series of issues, such as: "tensions with Budapest regarding Hungarian optants (...); formalizing and improving relations with Germany and other former enemy states during the first world war; reviving relations with Italy, in the St. Gothard (illegal transport of weapons from Italy to Hungary), which to a certain measure overlapped,

\footnotetext{
${ }^{17}$ Nicolae Titulescu, Pledoarii pentru pace, Conferinţă ţinută în Reischstag, Berlin, 6 May 1929, edited by George Potra and Constantin Turcu, Enciclopedica Publishing House, Bucureşti, 1996, p. 154

${ }^{18}$ Idem, pp. 160-161
}

(C) 2015. This work is licensed under the Creative Commons Attribution-Noncommercial-Share Alike 4.0 License. 


\section{"Mircea cel Batran" Naval Academy Scientific Bulletin, Volume XIX - 2016 - Issue 2 The journal is indexed in: PROQUEST / DOAJ / Crossref / EBSCOhost / INDEX COPERNICUS / DRJI / OAJI I JOURNAL INDEX I I2OR / SCIENCE LIBRARY INDEX / Google Scholar / Academic Keys/ ROAD Open Access I Academic Resources / Scientific Indexing Services / SCIPIO / JIFACTOR}

by its consequence in the European political life with Nicolea Titulescu's visit to Italy ; establishing a proper place and role for Romania as part of the European Danube Commission, at a time when they were debating amendments that were to be made to the legal status of this commission and the legal regime of maritime Danube so that the interests, independence and sovereignty of the country would not be hindered; the loan for economic and financial stabilization contracted by Romania; the ratification of the Concordat between Romania and the Vatican, etc" ${ }^{19}$

Central figure of Romanian and international political scene for almost a quarter of a century, Nicolae Titulescu distinguished himself by his activity in two Cabinets, as Romania's Ministry to London and as an extremely active primedelegate to the League of Nations, as supporter of Romania's diplomatic interests in the big capitals of the world, as originator and builder of regional security bodies such as the Little Entente or the Balkan Pact, etc. In 1935, Nicolae Titulescu was proposed as laureate of the Nobel Peace Prize ${ }^{20}$

"Titulescu's outlook on the defense and consolidation of peace rests on two extremely important factors: achieving a pacifist mentality, on the one hand, and legally organizing peace, on the other. Titulescu understood that beyond ethnicity and religion, frontiers, socio-political systems, alliances and ideologies, we all belong to the same big human family." 21

Given that Hungary expressed its intentions for rebuilding the old empire, some states in the Balkans understood the threat and mobilized to provide stability in the region by signing a series of international treaties. In 1920 negotiations started that led to the signing of the first important treaty aimed at countries in the region.

"Little Entente is the expression of a limited association to the defensive military alliance between Czechoslovakia, Yugoslavia and Romania against possible aggression from Hungary, acting alone or together with other States. This alliance was supplemented by a defensive alliance between Romania and Yugoslavia against possible aggression from Bulgaria, acting alone or with other countries." 22

By the signed treaties, Hungary was discouraged in its revisionist tendencies and forced to ponder on its intentions.

\footnotetext{
${ }^{19}$ George Potra and Costică Prodan, coord., Nicolae Titulescu, opera politico-diplomatică: iulie 1927-iulie 1928, part I, The Titulescu European Foundation, Bucureşti, 2003, p. XXIV

${ }^{20}$ Adrian Năstase, George G. Potra, coord., Titulescu, ziditor de mari idealuri, second edition, The Titulescu European Foundation, Bucureşti, 2008 p. 14

${ }^{21}$ Idem, p. 25

22 Nicolae Titulescu, Politica externă a României (1937), Editura Enciclopedică, Bucureşti,1994, p. 69
}

"Since its creation in 1921 by Take lonescu, Pašić and Beneš, the Little Entente sought to develop its field of action in different ways, such as, for example, by the Treaty of mutual arbitration, by the resolutions on their own rules of procedure, etc. But strange as it may seem, there was no similar trend in politics. Only the new Pact for the Organization of the Little Entente, signed in Geneva on February 16, 1933 (...) we decided to strengthen the unity of action of the Little Entente states, providing that none of the three states can conclude treaties with other Contracting states, or take any action capable of modifying their current international situation, or to sign economic agreements with major political consequences, without the consent of the other two parties." ${ }^{23}$

"With all the efforts of Titulescu, Romania has not always managed the provisions of the Treaty properly, in its own interest. Romanian government allowed the signing of a Treaty by Yugoslavia and Italy, whose provisions were contrary to Romania's national interests, especially since Hungarian revisionism in that moment was free to unfold. Yugoslavia, based on the Little Entente Treaty urged the agreement of governments in Bucharest and Prague. Romanian Government had no objection regarding this new situation created by Yugoslavia. On the other hand the Yugoslav government rose whenever deemed necessary, objections regarding Romania's foreign relations of with other countries, such as Bulgaria even though a few years later Yugoslavia signed a treaty with Bulgaria declaring it eternal friendly nation." 24

Maybe the signing of the 1934 treaty which laid the foundation of the Balkan Pact would have had a greater impact if Romania's relations with some neighboring countries were normalized. Tensions existed not only with Hungary but also with the USSR.

"Another area in which Nicolae Titulescu put his diplomatic skills in the service of Romania (...) was the settlement on modern bases of the European Danube Commission's work and clearly specifying the legal regime of the Danube in general and maritime Danube in particular.,"25

Nicolae Titulescu was a leading figure of international diplomacy between the wars. This is testified by documents, the correspondence between the great Romanian diplomat and prominent people of his time. Characterized by balance, intelligence and dignity, Nicolae Titulescu represents an important voice. Romania distinguished itself thanks to him. Romania's

\footnotetext{
${ }^{23}$ Idem, pp. 69-70

${ }^{24}$ Idem, p. 66 and the following

${ }^{25}$ George Potra and Costică Prodan, coord., op. cit., p. XXXIX
} 
"Mircea cel Batran" Naval Academy Scientific Bulletin, Volume XIX - 2016 - Issue 2 The journal is indexed in: PROQUEST / DOAJ / Crossref / EBSCOhost / INDEX COPERNICUS / DRJI / OAJI I JOURNAL INDEX I I2OR / SCIENCE LIBRARY INDEX / Google Scholar / Academic Keys/ ROAD Open Access I Academic Resources / Scientific Indexing Services / SCIPIO / JIFACTOR

position in the Balkans and in its relations with the

one.

\section{countries bordering the Black Sea was an active}

\section{BIBLIOGRAPHY}

[1] Agrigoroaiei, România Interbelică, vol. I, Alexandru Ioan Cuza University Press, laşi, 2001

[2] Stănescu Eugen, Stănescu lulia, Preda Gavriil, România Mare. Puterea politică, Karta-Graphic Publishing, Ploieşti, 2010

[3] Cernea Emil, Molcuţ Emil, Istoria statului şi dreptului românesc, Şansa-S.R.L. Press and Publishing House,Bucureşti 1998

[4] Boia Lucian, Suveranii României. Monarhia, o soluţie?, Humanitas Publishing House, Bucureşti, 2014

[5] Boia Lucian, De ce este România altfel?, ediţia a II-a, Humanitas Publishing House, Bucureşti, 2013

[6] Mihăilescu Dan C., Castelul, Biblioteca, Puşcăria. Trei vămi ale feminitătii, Humanitas Publishing House, Bucureşti, 2013

[7] Năstase Adrian, Potra G. George, coord., Titulescu, ziditor de mari idealuri, ediţia a 2-a, The Titulescu European Foundation, Bucureşti, 2008

[8] Titulescu Nicolae, Pledoarii pentru pace, edited by George Potra and Constantin Turcu, Enciclopedica Publishing House, Bucureşti, 1996

[9] Titulescu Nicolae, Politica externă a României (1937), Enciclopedica Publishing House, Bucureşti,1994

[10] Potra George, Prodan Costică, coord., Nicolae Titulescu, opera politico-diplomatică: iulie 1927-iulie 1928, part I,II, The Titulescu European Foundation, Bucureşti, 2003 